\title{
DIAGNOSTIC SIGNIFICANCE OF BIOCHEMICAL INDICATORS OF LIVER FIBROGENESIS IN ADOLESCENTS WITH OBESITY
}

\section{O. V. BUZNYTSKA}

\author{
Kharkiv Medical Academy of Postgraduate Education, \\ V. N. Karazin Kharkiv National University, Ukraine \\ e-mail:ebuznickaa@ukr.net; missbuzelena@gmail.com
}

Received: 27 September 2018; Accepted: 13 December 2018

Non-alcoholic fatty liver disease occurs in most obese people, the main pathway of which is the process of fibrogenesis. The aim of this work was to determine the potential biomarkers for early diagnosis of liver fibrogenesis in adolescents with obesity. The levels of liver fibrosis markers, such as fibronectin, collagen type IV, $N$-terminal propeptides and C-terminal telopeptides of type I collagen, were assessed with the use of IFA method in serum of 226 patients with obesity aged 8-18 years. A significant increase in levels of type IV collagen and fibronectin was observed in children with obesity $(P<0.05)$. As diagnostic criteria for fibrogenesis and fibrolysis, the levels of $N$-terminal propeptides and $C$-terminal telopeptides of type I collagen, respectively, were determined. The serum level of $N$-terminal propeptides of type I collagen significantly exceeds the normal values in all children with obesity compared to the control group $(P<0.05)$. The biochemical markers (type IV collagen, fibronectin, $N$-terminal propeptides and $C$-terminal telopeptides of type I collagen) were proven to have high diagnostic informative value in the early diagnosis of liver fibrogenesis in obese adolescents. It was shown that the signs of fibrosis in non-alcoholic fatty liver disease already occur at the stage of steatosis.

Keywords: adolescents, non-alcoholic fatty liver disease, liver fibrosis, obesity, diagnostics methods.

I $\mathrm{n}$ modern hepatology, many factors that contribute to the development of chronic diffuse liver disease are known. These include viruses, alcohol, drug compounds, toxins, genetically caused metabolic disorders. Currently, non-alcoholic fatty liver disease (NAFLD) is one of the most common chronic liver diseases in the world, which combines the range of clinical and morphological changes represented by steatosis, steatohepatitis, steatofibrosis and liver cirrhosis [1-4]. The modern model of the pathogenesis of NAFLD is represented by the theory of "two strokes", the first of which is the development of fatty degeneration, the second one is steatohepatitis. Upon obesity, especially abdominal, and in conditions of insulin resistance (IR), the lipolysis of adipose tissue increases leading to an increase in the supply of free fatty acids to the liver and the formation of steatosis. This is seen as the "first blow".
Prolonged increase in the level of free fatty acids in hepatocytes causes mitochondrial dysfunction, which contributes to the microsomal oxidation of lipids by the cytochrome P450 system with the formation of reactive oxygen species [5-7]. The oxidative stress, the "second blow", occurs. That results in increased formation of proinflammatory cytokines with the formation of inflammatory reactions in the liver and the development of steatohepatitis. At certain stages of inflammation, cellular infiltration and dystrophy are joined by the activation of liver stem cells, which begin to synthesize the components of the intercellular matrix in surplus quantities (collagen of various types, laminin, fibronectin, and others). The onset of fibrogenesis is accompanied, in most cases, by the decrease of signs of inflammation and the predominance of fibrosis, which leads to a violation of the organ structure with the subsequent

(C) 2019 Buznytska O. V. This is an open-access article distributed under the terms of the Creative Commons Attribution License, which permits unrestricted use, distribution, and reproduction in any medium, provided the original author and source are credited. 
development of liver cirrhosis and even hepatocellular carcinoma $[8,9]$.

One of the components of the intercellular space is fibronectin. This glycoprotein is a "molecular glue" that promotes the fixation of cells in the intercellular space by interacting with membrane receptors, and also enhances phagocytosis [10]. With the development of fibrosis, both the quantitative and qualitative composition of the intercellular matrix vary, in particular, the level of collagen of different types increases. One of the first in various liver lesions is collagen type IV, which is the main structural element of cellular basement membranes. The level of collagen type IV reflects current hepatocellular damage in the initial stages and processes of liver regeneration $[11,12]$. In the future, the accumulation of other types of collagen, in particular type I, leads to the formation of bridge-like fibrosis and ultimately contributes to the development of cirrhosis. $\mathrm{N}$-terminal propeptides and C-terminal telopeptides of type I collagen are used as diagnostic criteria for fibrosis and fibrolyses, respectively [13].

The actual incidence of the disease is difficult to establish, due to the inadequate use of biochemical screening diagnostic methods, through which the initial forms of the disease can be detected [14-16]. To date, the most informative and objective method of diagnosis of NAFLD remains liver biopsy, which provides the possibility to assess the stage, exclude other causes of liver damage and predict further course of the disease [17]. But due to significant restrictions, namely: the acquisition of informative material, the risk of complications, childhood, the complexity of further dynamic observation, there are grounds for the development of non-invasive, safer and more sensitive diagnostic methods, mainly biochemical and molecular, which highly correlate with the parameters of liver biopsy and easly available in clinical practice [18]. Therefore, in recent years, interest in the search for biochemical markers of liver fibrogenesis [19] has become considerably aggravated, which in the future would contribute to the development of algorithms for primary prevention and early diagnosis of NAFLD.

The aim of this work was to study the diagnostic significance of biochemical markers of liver fibrogenesis in adolescents with obesity.

\section{Material and Methods}

The research was performed at the endocrinology department of SI "Institute of children and adolescence health care of NAMS” (Kharkov). 226 children with obesity aged 8 to 18 years were examined: 129 males (57.08 $\pm 3.29 \%), 97$ females (42.92 $\pm 3.29 \%)$. The control group consisted of 30 healthy children of the same age group. To assess the functional status of the liver in adolescents with obesity, a complex of clinical, laboratory, biochemical and instrumental research methods was used. The criterion for IR was the homeostatic model HOMA IR (Homeostasis model assessment of Insulin Resistance, Matthews D.R., 1985). The calculation was made using formula: HOMA $=(\mathrm{G} 0 \cdot \operatorname{Ins} 0) / 22.5 ;(\mathrm{G} 0-$ fasting glucose level of the blood serum, $\mathrm{mmol} / \mathrm{l}$; Ins 0 - content of insulin in blood serum, $\mu \mathrm{U} / \mathrm{ml}$. The Result is more than 3.5 units testified to the presence of IR.

Immunoassay analysis was used to determine the biochemical markers of the intensity of liver fibrogenesis, namely fibronectin in plasma (Fibronectin ELISA Kit, Company Biohimmak (RF)), serum type IV collagen (Serum collagen IV EIA, Argutus Medical (Japan)) in blood, $\mathrm{N}$ - terminal propeptides of type I collagen (NT-proCNP, Biomedica (Austria)) and C-terminal telopeptides of type I collagen (Serum CrossLaps Elisa, Immunodiagnostic Systems Ltd (UK)). Blood collection and stabilization were carried out according to the instructions for the kits. The reference maximum value for collagen type IV is $99.0 \pm 2.3 \mu \mathrm{g} / 1$ in serum; while fibronectin is $70.0 \pm 14.0 \mu \mathrm{g} / \mathrm{ml}$ in blood plasma. The concentration of N-terminal propeptides and C-terminal telopepeptides of type I collagen in serum varies depending on age and sex.

Database creation and statistical processing of the results were performed on IBM-Pentium III using application packages "Stadia-6" (serial number of license certificate 1218 May 24, 2000, version "Prof"), Microsoft “Access", "Excel”. The $t$-criterion of the Student (p) was used to assess the likelihood of differences, as well as correlation analysis. The critical significance level for checking statistical hypotheses when comparing groups was assumed to be 0.05 . Ethical norms at all stages of the survey were observed. The work was conducted taking into account the requirements of the European Convention (Strasbourg, 1986), the provisions of the ICH GCP (2008), GLP (2002). Studies did not cause psychological discomfort in patients. Patients and their parents were provided with information on the methods and scope of the research, signed informed consent to participate in the study. 


\section{Results and Discussion}

IR was identified in 113 of 226 (50.0\%) patients, according to the results of the index NOMA-IR.

The study of biochemical parameters of fibrosis (Table 1) revealed a significant increase in levels of collagen type IV and fibronectin in adolescents with obesity $(P<0.05)$. The levels of fibronectin in the blood significantly differed in groups depending on the presence of IR, which indicates a more severe liver damage in adolescents with IR $(P<0.05)$.

Individual analysis of patients in groups was made. It showed these indicators in obese patients, maximum levels for type IV collagen: $232.11 \mu \mathrm{g} / 1$ in a teenager with IR; $198.11 \mu \mathrm{g} / \mathrm{l}$ - without IR and fibronectin: $253.2 \mu \mathrm{g} / \mathrm{ml}$ in patient with IR; $200.0 \mu \mathrm{g} /$ $\mathrm{ml}$ - without IR. It should be noted that it was in these patients that according to ultrasound examination of the liver, were the most distinct changes: a sharp increase in the liver, a decrease in echogenicity, seizure of the walls of the vessels, indicating unfavorable dynamics of the disease. Using correlation analysis, a statistically valid direct relationship of average strength was found between the levels of biochemical markers and ultrasound results $(r=+0.4 ; P<0.05)$.

As the diagnostic criteria of the two physiologically antagonistic processes - fbrogenic and fbrosis, we determined the levels of $\mathrm{N}$-terminal propeptides and C-terminal telopeptides of type I collagen, respectively, with subsequent assessment of the benefits of one of them.

The results obtained for $\mathrm{N}$-terminal propeptides of type I collagen in serum are presented in Table 2, which shows that its level significantly exceeds the reference values in all obese adolescents, unlike children in the control group $(P<0.05)$.
Table 1. Levels of type IV collagen and fibronectin in adolescents with obesity $(M \pm \sigma)$

\begin{tabular}{c|c|c}
\hline $\begin{array}{c}\text { Groups } \\
\text { of patients }\end{array}$ & $\begin{array}{c}\text { Collagen } \\
\text { type IV, } \mu \mathrm{g} / 1\end{array}$ & $\begin{array}{c}\text { Fibronectin, } \\
\mu \mathrm{g} / \mathrm{ml}\end{array}$ \\
\hline Control group & $85.91 \pm 2.38$ & $78.36 \pm 2.12$ \\
IR+ & $107.61 \pm 7.04^{*}$ & $115.86 \pm 7.20^{* * * *}$ \\
IR- & $103.76 \pm 8.31^{*}$ & $93.00 \pm 6.31^{*}$
\end{tabular}

Control group $(n=30)$; IR+ and IR- $(n=113) .{ }^{*}$ Difference between patients with obesity and healthy children $(P<0.05) .{ }^{* *}$ Difference between patients with IR and without it $(P<0.05)$

It should be noted that in teenagers with IR, the levels of N-terminal propeptides type I collagen were more elevated than in the non-IR group, which indicates an intensive process of liver fibrosis in presence of IR $(\mathrm{P}<0.05)$. In the prepubertal period, this indicator was significantly higher in girls with IR (11.12 \pm 1.6$)$, unlike boys (9.03 \pm 0.21$)$ $(P<0.05)$, and in the postpubertal period, on the contrary - boys with IR had significantly higher values of N-terminal propeptides $(8.28 \pm 0.8)$ than girls $(5.51 \pm 0.88)(P<0.05)$. It is connected with the fact that in the prepubertal and puberty period, the growth spurt of girls is physiologically faster than that of boys who "catch up" with girls in the middle of puberty and postpuberty periods.

Thus, the exchange of connective tissue, its regeneration is most active during intense growth. In the group of children without IR, the level of biochemical markers in pubertal and postpubertal adolescent boys $(9.536 \pm 1.84$ and $7.806 \pm 0.94$ respectively) significantly exceeded the rates among girls of the same age $(6.903 \pm 0.61$ and $4.536 \pm 0.52$, respectively) $(P<0.05)$. That is, it can be argued that

Ta ble 2. Levels of the $N$-terminal propeptides type I collagen in adolescents with obesity $(M \pm \sigma)$

\begin{tabular}{|c|c|c|c|c|c|c|}
\hline \multirow{3}{*}{$\begin{array}{l}\text { Groups } \\
\text { of patients }\end{array}$} & \multicolumn{6}{|c|}{ N-terminal propeptides of type I collagen, pmol/l } \\
\hline & \multicolumn{2}{|c|}{ Prepubertal period $(n=32)$} & \multicolumn{2}{|c|}{ Pubertal period $(n=92)$} & \multicolumn{2}{|c|}{ Postpubertal period $(n=102)$} \\
\hline & boys & girls & boys & girls & boys & girls \\
\hline $\begin{array}{l}\text { Control gro } \\
(n=30)\end{array}$ & $4.45 \pm 0.13$ & $5.64 \pm 0.14$ & $6.21 \pm 0.1$ & & $5.08 \pm 0.13$ & $3.79 \pm 0.11$ \\
\hline $\mathrm{IR}+(n=113)$ & $9.03 \pm 0.21^{*}, * *$ & $11.12 \pm 1.60 * * *$ & $8.60 \pm 1.04^{*}$ & $7.42 \pm 0.76^{*}$ & $8.28 \pm 0.80 * * *$ & $5.51 \pm 0.88 * * *$ \\
\hline $\mathrm{IR}-(n=113)$ & $6.98 \pm 0.65^{*}$ & $5.90 \pm 0.77^{*}$ & $9.536 \pm 1.84^{*}$ & $6.903 \pm 0.61^{*}$ & $7.806 \pm 0.94 *$ & $4.536 \pm 0.52 *$ \\
\hline
\end{tabular}

* Difference between patients with obesity and healthy children $(P<0.05)$. ** Difference between patients with IR and without it $(P<0.05)$ 
Ta ble 3. Indicators of C-terminal telopeptides of type I collagen in adolescents with obesity $(M \pm \sigma)$

\begin{tabular}{l|c|c|c|c|c|c}
\hline \multirow{2}{*}{$\begin{array}{c}\text { Groups } \\
\text { of patients }\end{array}$} & \multicolumn{6}{|c}{ C-terminal telopeptides of type I collagen, ng/ml } \\
\cline { 2 - 7 } & Prepubertal period $(n=32)$ & Pubertal period $(n=92)$ & \multicolumn{2}{c}{ Postpubertal period $(n=102)$} \\
\cline { 2 - 7 } & boys & girls & boys & girls & boys & girls \\
\hline Control group & & & & & & \\
$(n=30)$ & $1.52 \pm 0.32$ & $1.89 \pm 0.43$ & $2.61 \pm 0.71$ & $2.47 \pm 0.68$ & $1.23 \pm 0.25$ & $0.89 \pm 0.19$ \\
IR+ $(n=113)$ & $1.86 \pm 0.41$ & $1.921 \pm 0.14$ & $1.88 \pm 0.18^{*}$ & $1.673 \pm 0.18^{*}$ & $1.291 \pm 0.08$ & $1.134 \pm 0.14^{* *}$ \\
IR- $(n=113)$ & $1.72 \pm 0.25$ & $1.927 \pm 0.42$ & $1.888 \pm 0.34^{*}$ & $1.281 \pm 0.10^{*}$ & $1.218 \pm 0.13$ & $0.733 \pm 0.06$ \\
\hline
\end{tabular}

* Difference between patients with obesity and healthy children $(P<0.05)$. ** Difference between patients with IR and without it $(P<0.05)$

there are early stages of liver fibrosis in adolescents with obesity, which are more prominent in those surveyed with IR. The levels of the studied index in the control group were within the normal range $(P<0.05)$.

The results of C-terminal telopeptides of type I collagen in serum are presented in Table 3.

As can be seen from the data obtained, the levels of C-terminal telopeptides of type I collagen in obese adolescents were within the reference norms and did not differ statistically significantly from such control groups $(P>0.05)$. Exceptions are the children of puberty age, both with IR (1.88 \pm 0.18 boys and $1.673 \pm 0.18$ girls) and without it (1.888 \pm 0.34 boys and $1.281 \pm 0.10$ girls), whose fibrolysis marker indices were significantly lower than in control group of children (2.61 \pm 0.71 males and $2.47 \pm 0.68$ girls $)(P<0.05)$. Most likely, this is due to the predominance of fibrogenesis over fibrolysis processes, which is characteristic of liver fibrosis. There was also a significant prevalence of this indicator in girls of postpubertal age with IR, as opposed to girls without IR $(1.134 \pm 0.14$ and $0.733 \pm 0.06$ respectively, $P<0.05$ ).

According to the results of the correlation analysis, in adolescents with IR a direct correlation of average strength between the level of N-terminal propeptides and C-terminal telopeptides of type I collagen $(r=0.461 ; P<0.01)$ was established. Thus, with the predominance of fibrogenesis processes, the system of fibrolysis is automatically activated to maintain the physiological balance of the connective tissue metabolism. In patients without IR, a direct correlation of average strength between the content of propeptides and telopeptides of type I collagen ( $r=0.452 ; P<0.001)$ was also established; and so was a strong correlation between the levels of col- lagen type IV and C-terminal telopetides ( $r=0.709$; $P<0.05$ ) and average strength correlation with the level of N-terminal propeptides of type I collagen $(r=0.467 ; P<0.05)$.

Thus, the obtained data indicate the presence of fibrogenesis processes even at the initial stages of fatty liver disease in adolescents with obesity. The proof is that there is a significant increase in levels of collagen type IV and fibronectin, in contrast to the control group $(P<0.05)$. Indicators of fibronectin significantly differed in groups depending on the presence of IR, which is probably associated with more severe liver damage in children with IR $(P<0.05)$. The established changes in $\mathrm{N}$-terminal propeptides and C-terminal telopeptides of type I collagen indicate the predominance of fibrogenesis processes over fibrolysis processes, which also indicate the presence of the early stages of liver fibrosis, long before the clinical manifestation of NAFLD and confirmation by available diagnostic methods.

Thus, non-invasive methods of diagnosis using biochemical markers of liver fibrosis (collagen type IV, fibronectin, N-terminal propeptides and C-terminal telopeptides type I collagen) confirmed their diagnostic value in establishing the early stages of liver fibrosis in adolescents with obesity.

In the long term, this will improve the effectiveness of early diagnosis of fatty liver disease, the dynamic monitoring of patients by checking the biochemical indicators of liver fibrosis and improve treatment and preventive measures.

Conflict of interest. Authors have completed the Unified Conflicts of Interest form at http:// ukrbiochemjournal.org/wp-content/uploads/2018/12/ coi_disclosure.pdf and declare no conflict of interest. 


\section{ДІАГНОСТИЧНЕ ЗНАЧЕННЯ БІОХІМІЧНИХ ПОКАЗНИКІВ ФІБРОГЕНЕЗУ ПЕЧІНКИ В ПІДЛІТКІВ 3 ОЖИРІННЯМ}

\section{О. В. Бузницька}

\author{
Харківська медична академія \\ післядипломної освіти; \\ Харківський національний університет \\ імені В. Н. Каразіна, Україна; \\ e-mail: ebuznickaa@ukr.net; \\ missbuzelena@gmail.com
}

Неалкогольна жирова хвороба печінки, основним шляхом прогресування якої $є$ процес фіброгенезу, зустрічається в більшості людей 3 ожирінням. Метою дослідження було визначення діагностичного значення біохімічних маркерів у ранній діагностиці фіброгенезу печінки в підлітків 3 ожирінням. Методом IEA вивчали показники фіброгенезу печінки (колаген IV типу, фібронектин, N-термінальні пропептиди і C-термінальні телопептиди колагену I типу) у 226 хворих з ожирінням у віці 8-18 років. Встановлено вірогідне збільшення рівнів колагену і фібронектину IV типу $(P<0,05)$ та рівнів $\mathrm{N}$-термінальних пропептидів і C-термінальних телопептидів колагену I типу в сироватці крові у всіх дітей з ожирінням порівняно 3 контролем $(P<0,05)$. Доведено високу інформативність визначення біохімічних маркерів у ранній діагностиці фіброгенезу печінки у хворих на ожиріння. Показано, що початок фіброгенезу за неалкогольної жирової хвороби печінки в підлітків 3 ожирінням має місце вже на етапі стеатозу.

К л ю ч о в і с л о в а: підлітки, неалкогольна жирова хвороба печінки, фіброгенез печінки, ожиріння, методи діагностики.

\section{References}

1. Ivashkin V. T. Diagnosis and treatment of nonalcoholic fatty liver disease. M.: MEDpressinform, 2012. $436 \mathrm{p}$.

2. Parkhomenko LK, Strashok LA, Eshchenko AV, Buznytskaya EV. Problems of diagnosis of nonalcoholic fatty liver disease in adolescence. Child Health. 2011; 7(34): 107-112.

3. Chalasani N, Younossi Z, Lavine JE, Diehl AM, Brunt EM, Cusi K, Charlton M, Sanyal AJ. The diagnosis and management of non-alcoholic fatty liver disease: Practice guideline by the American Association for the Study of Liver Diseases, American College of Gastroenterology, and the American Gastroenterological Association. Am J Gastroenterol. 2012; 107(6): 811-826.

4. Della Corte C, Alisi A, Saccari A, De Vito R, Vania A, Nobili V. Nonalcoholic fatty liver in children and adolescents: an overview. $J$ Adolesc Health. 2012; 51(4): 305-312.

5. Polyzos SA, Mantzoros CS. Nonalcoholic fatty future disease. Metabolism. 2016; 65(8): 10071016.

6. Musso G, Gambino R, Cassader M, Pagano G. Meta-analysis: natural history of non-alcoholic fatty liver disease (NAFLD) and diagnostic accuracy of non-invasive tests for liver disease severity. Ann Med. 2011; 43(8): 617-649.

7. Yeloieva ZV , Strashok LA, Buznytska OV, Filonova TO, Shtrakh KV. Functional state of gepatobiliary system of children with obesity. Probl Uninterrupted Med Train Sci. 2017; 4: 3742.

8. Jayakumar S, Harrison SA, Loomba R. Noninvasive Markers of Fibrosis and Inflammation in Nonalcoholic Fatty Liver Disease. Curr Hepatol Rep. 2016; 15(2): 86-95.

9. Bloomgarden ZT. Second World Congress on the Insulin Resistance Syndrome: insulin resistance syndrome and nonalcoholic fatty liver disease. Diabetes Care. 2005; 28(6): 1518-1523.

10. Babak OYa, Kravchenko NA. Serum biomarkers and fibrotests in the diagnosis of liver fibrosis: disadvantages and prospects. Modern Gastroenterol. 2012; (3(65)): 71-80.

11. Alkhouri N, Feldstein AE. Noninvasive diagnosis of nonalcoholic fatty liver disease: Are we there yet? Metabolism. 2016 Aug;65(8):1087-95.

12. Papagianni M, Sofogianni A, Tziomalos K. Non-invasive methods for the diagnosis of nonalcoholic fatty liver disease. World J Hepatol. 2015; 7(4): 638-648.

13. McPherson S, Stewart SF, Henderson E, Burt AD, Day CP. Simple non-invasive fibrosis scoring systems can reliably exclude advanced fibrosis in patients with non-alcoholic fatty liver disease. Gut. 2010; 59(9): 1265-1269.

14. Al-Hamad D, Raman V. Metabolic syndrome in children and adolescents. Transl Pediatr. 2017; 6(4): 397-407.

15. Mantovani A, Zaza G, Byrne CD, Lonardo A, Zoppini G, Bonora E, Targher G. Nonalcoholic 
fatty liver disease increases risk of incident chronic kidney disease: A systematic review and meta-analysis. Metabolism. 2018; 79: 64-76.

16. O'Neill S, O'Driscoll L. Metabolic syndrome: a closer look at the growing epidemic and its associated pathologies. Obes Rev. 2015; 16(1): $1-12$.

17. Cholongitas E, Senzolo M, Standish R, Marelli L, Quaglia A, Patch D, Dhillon AP, Burroughs AK. A systematic review of the quality of liver biopsy specimens. Am J Clin Pathol. 2006; 125(5): 710721.
18. Sanai FM, Keeffe EB. Liver biopsy for histological assessment: The case against. Saudi J Gastroenterol. 2010; 16(2): 124-132.

19. Shah AG, Lydecker A, Murray K, Tetri BN, Contos MJ, Sanyal AJ. Comparison of noninvasive markers of fibrosis in patients with nonalcoholic fatty liver disease. Clin Gastroenterol Hepatol. 2009; 7(10): 1104-1112. 